\title{
BIM for heritage science: a review
}

\author{
Danae Phaedra Pocobelli ${ }^{1 *} \mathbb{B}$, Jan Boehm², Paul Bryan ${ }^{3}$, James Still ${ }^{4}$ and Josep Grau-Bové ${ }^{1}$
}

\begin{abstract}
Building Information Modelling (BIM) is a new process that is spreading in the Architecture, Engineering and Construction field. It allows the creation of virtual building models, which can be linked to numerical data, texts, images, and other types of information. Building components, such as walls, floors, etc. are modelled as "smart objects", i.e. they are defined by numerical parameters, such as dimensions, and are embedded with other kinds of information, such as building materials and properties. Stored data are accessible and modifiable by all different professionals involved in the same project. The BIM process has been developed for new buildings, and it allows to plan and manage the whole building life-cycle. BIM for built heritage has started to be researched recently, and its use is still not widespread. Indeed, built heritage is characterised by complex morphology and non-homogeneous features, which clash with BIM's standardised procedures. Moreover, to date, BIM does not allow fully automated procedures to model heritage buildings. This review focuses on the survey and digitisation phases, which can be seen as the initial phases of application of BIM in conservation projects. It also briefly covers the modelling stage. Here we present the main methodologies developed for BIM for built heritage. Issues about digitisation are also highlighted, principally in connection with the unavailability of automated processes. During the last 10 years, research has led to promising results; for example, videogame interfaces have been used to simulate virtual 3D tours that display in a single interface the 3D model and the database containing metadata, and new software plug-ins have been developed, to easily create "smart objects". Nevertheless, further research is needed to establish how BIM can support the practice of building conservation. There is a gap in BIM's information holding capacities, namely the storage of cultural and historical documentation, as well as monitored and simulated data relevant for preventive conservation. Future work should focus on the development of new tools that will be able to store and share all the relevant metadata.
\end{abstract}

Keywords: BIM, HBIM, Heritage building, Conservation, Survey, Parametric smart object library, Smart object, Point cloud

\section{Introduction}

In the last decades, a quick development in Information Technology (IT) has taken place, and architectural representation procedures have been affected by it. At the end of the last century, professionals could use Computer Aided Design (CAD) to draw their projects without formal procedures to share and store the associated metadata. Nowadays a key development is taking place under the name of Building Information Modelling (BIM). Using BIM technology, it is possible to condense all the information required during building works in one single

\footnotetext{
*Correspondence: danae.pocobelli.15@ucl.ac.uk

${ }^{1}$ The Bartlett School of Environment, Energy and Resources, Institute for Sustainable Heritage, University College London, Central House, 14 Upper Woburn Place, London WC1H ONN, UK

Full list of author information is available at the end of the article
}

file [1-7], creating what has been called "smart" models $[1,3]$.

Building Information Modelling should be considered a process, rather than a technology. It is a three-dimensional (3D) project computational representation that connects all the available information to each $3 \mathrm{D}$ object of the model [3, 7]. Whilst a CAD is essentially a 3D model that allows creating plans, sections, etc., but still formed by purely geometrical elements, a smart model has all its elements linked to a database containing all the related metadata $[1,2,6]$. The expression "smart models" refers to models composed of parametric objects $[4,5$, $8-23$ ], i.e. virtual building components that are identified by modifiable parameters, such as dimensions. These virtual objects may also contain other types of data, such as material information $[4,5,7-9,19,20,23-26]$, and they 
are an accurate-for conservation purposes-representation of the corresponding real ones [3]. Murphy et al. [19] enhance this notion, and they claim that, in BIM, parameters are assigned prior to the modelling phase. This means that they can be modified anytime as needed $[7,13,14,19,22,27,28]$. This feature may become crucial for heritage buildings, as models need to be updated frequently due to new discoveries or new interpretations $[5,7,23]$, interventions $[2,7,29]$ or unintended changes in the building fabric such as weathering processes $[1,4$, $5,8,20]$.

Building Information Modelling allows controlling buildings from their planning phase until their management, maintenance and, eventually, their restoration $[2$, $5,30]$. Various authors $[2,3,7,17]$ emphasise that one of the most interesting properties in BIM is interoperability. Different professionals are usually involved in a building project $[5,21]$, and through BIM's flexibility, they are able to access all information they may need [3, 5, 16, 19, 21].

Currently BIM is mostly applied to buildings under construction, rather than to existing ones [5, 7, 23, 31]; this has been attributed by some to the scepticism of heritage professionals $[17,23]$, but it may also happen because the effort of modelling and converting to smart objects is high, and, while handling data, existing buildings usually have problems of uncertainty and interpretation [23]. Moreover, heritage buildings usually do not allow standardisation procedures-which are BIM's strength-, as they are the result of different historical layers, additions and demolitions, changes of use/function, etc.

This paper is not a "conventional" state-of-the-art literature review; it rather assesses the use of BIM within the Heritage sector, with practical case study references. Two literature reviews exist on the use of BIM in built heritage. Logothetis [16] presents a complete account of software platforms and the steps involved in the creation of BIM models of existing buildings, focusing also on the difference between CAD and BIM-identified in the concept of "information". The second one [23] revises many historic BIM projects to conclude that the main challenges to the use of BIM in historic buildings are "(i) the automation of data capture and BIM creation (ii) the update and maintenance of information in BIM and (iii) the handling and modelling of uncertain data" [23]. In this context, "uncertain data" refers to spatial and component data which are not easily standardisable.

The present review addresses issues that have not been explicitly discussed in previous research. Firstly, it explores the use of BIM to capture and store the typologies of data that can support heritage science, or in other words, the scientific analysis of historic buildings. Specifically, it aims to explain how BIM can be used to support the documentation of heritage buildings during conservation processes. Secondly, it identifies which areas need further research for the purpose of using BIM in heritage science processes: monitoring, forecasts and preventive conservation. Finally, it discusses the latest technological developments of this rapidly evolving field.

\section{Building conservation practice}

Building conservation is a complex and multi-layered process that requires collaboration between different specialists [2, 29]. Many of the data typologies involved in this process could, in principle, be introduced in building models that can enable collaboration. This section lists the types of information that could potentially be part of an Historic Building Information Modelling (HBIM). In the following sections, the potential of this implementation is assessed critically.

One of the key phases is the building analysis, during which a great diversity of information sources needs to be combined [29, 32-34]. Traditionally, building analysis is carried out using manual methods, especially in the survey phase. Through triangulation and Digital Photogrammetry, it is possible to obtain the geometric and the texture/material properties of a building; this information is then digitised on a CAD platform, and a 3D model is produced. At the same time, historical analysis is performed, examining past sources, documentation, and generally all existing evidence [34]. The next step is to detect any surface degradation and to plan an intervention session accordingly.

Ordinary information for heritage building to be conserved include:

1. Geometrical data, such as dimensions and volumetry [32];

2. Architectural grammar, intended as architectural style. It could include specific building components and construction techniques [32];

3. Material characterisation [32, 35]. This information is commonly detailed with elevation views where each material is depicted with a different hatch. The hatches are then illustrated by labels;

4. Façade degradation [32, 36]. Elevation views are embedded with hatches representing specific degradations. Degradation typologies may be described using glossaries, such as the ICOMOS-ISCS [37];

5. Façade interventions. Facade degradation scripts are used to plan specific interventions. Intervention handouts are again elevation views embedded with hatches, symbols and tables to detail planned actions.

6. If the building is suffering from any structural damage, a damage survey is required [32] to adequately plan structural consolidation interventions. 
7. Data collection, and possibly simulation, of environmental parameters and their future effects on the building fabric, inform the maintenance of the building and support-decision making. Recent developments in the prediction and interpretation of risks to buildings may be used, such as Computational Fluid Dynamics (CFD) simulations [38, 39] and spatially resolved monitoring data [40].

Conservation practice is usually carried out with the involvement of many different professionals, and it is common to face issues of data loss and data replication $[1,41,42]$.

\section{BIM in heritage}

This section reviews the different usage of BIM in heritage and assesses which areas are under active development.

\section{Survey}

Surveying a building means detecting its dimensions, its geometry, its style, its materials, etc. This phase is crucial, as it helps to enhance the understanding of the building [34], and actively supports conservation planning [34, 43].

Traditionally, surveys were carried out with the triangulation methodology, which consists of taking measurements manually, fixing reference-points (called stations) and triangulating every corner through a laser device or a meter rule tape. Error propagation is contained, since every point of the building is determined through two measures [44].

The current trend is, however, to combine Digital Photogrammetry with Laser Scanning, as described in many of the articles reviewed $[7-9,15,18,19,34,41,42,45-$ 52]. Digital Photogrammetry is based on the triangulation principle $[18,52,53]$, as the images produced are taken from different viewpoints [52]. Combining it with Laser Scanning allows the capture of high-resolution photographs of materials' textures $[1,18,32,53,54]$ and as a consequence, information of material degradation [32]. The photographs need to be post-processed, and this is normally possible with just one piece of software $[4,8]$. However, the combination of Laser Scanning outputs and Digital Photogrammetry ones can be delicate, as the devices must be both properly calibrated, and error propagation is likely to occur [53]. It is also possible to compose a structure from high-resolution images through Structure from Motion (SfM) [50, 55] methodology. SfM is based on the principle that 4 non-coplanar surfaces can be detected by three orthographic projections [55]. This method consists in taking photographs moving the camera continuously, trying to detect convergent images, and then digitally reconstructing the geometry [55].

Some Terrestrial laser scanners (TLS) are based on the triangulation principle as well $[2,18,53,56]$. They produce a point cloud of the scanned object [49], which needs to be post-processed and then is transformed into a $3 \mathrm{D}$ model $[4,8,18,49,57,58]$. Point clouds post-processing is still a time-consuming task [23, 29, 57], even if there have been some attempts to speed it up [15, 48, $49,59,60]$. TLS can be integrated with Geographic Information System (GIS), to geo-locate the scanned object through Cartesian coordinates and to analyse geospatial data [2, 11, 22, 24]. Latest techniques use Unmanned Aerial Vehicle (UAV, commonly known as drones) with GIS to scan the surroundings. This is particularly useful when the landscape is connected to the studied building, as it has been done for the Borobudur Temple [51].

\section{Point cloud post-processing}

$T L S$ outputs are point clouds and need to be processed to be used in building the BIM model [34]. There are not specific heritage-related issues with this practice; however, it is a propaedeutic task to build the BIM model.

The most common operations are:

- Noise elimination [8, 18, 23], which consists in detecting and eliminating scanned items that are not part of the case study;

- Point cloud registration $[8,18,49,57,58]$, which consists in merging different point clouds of the same object, deriving from different scanning sessions;

- Meshing [18, 29, 57], which consists of creating triangulated surfaces to be turned into 3D models afterwards-to be done with specific software.

This task is long and elaborate, but there are some attempts to automate it $[15,41,48,49,57,61]$. Automation is an aspect where research is strongly active, as it would allow quicker and cheaper surveys when applied to the heritage sector. Moreover, an architect/restorer charged to digitise and provide a conservation project of a heritage building, would be struggling if they had to manually post-process point clouds by themselves. These tasks are not particularly straightforward, and very often specific photogrammetry knowledge is required.

For instance, Garagnani developed a new plug-in, called GreenSpider, which helps in the automation of importing point clouds [15, 48, 49]. GreenSpider imports some selected points of the point cloud and it transforms them into snaps (i.e. reference points), allowing the bonds to be retraced and converted into 3D smart objects. Practically, GreenSpider allows the user to select which points of the cloud are needed, and it converts them into masses 
(i.e. 3D undefined objects). These masses can be imported in any 3D modelling platform-after being embedded with semantic information, such as materials, dimensions, etc., and then be inserted into the BIM model as "families", i.e. categories of similar objects. Additionally, a metadata enrichment can be provided by saving GreenSpider objects as Industry Foundation Classes (IFC). IFC is an exchange file format standard that describes virtual objects able to store information and data. ${ }^{1}$ GreenSpider is a noteworthy example of automation endeavours, as it has been designed to run directly on a BIM platform as a plug-in. This study tries to overcome typical conversion problems that are often faced with heritage BIM. However, the process is rather long and laborious, and it should be considered as a work-in-process research.

Other attempts of automation of post-processing have been made. In 2014, Oreni et al. [59, 60] developed a methodology using Non Uniform Rational Basis Splines (NURBS). NURBS allow modelling through vector extraction from point clouds using mathematical functions. Another example is the Cloud-to-BIM-to-FEM [62] method, which is not exactly an automation, it is rather a procedure that converts point clouds to BIM and then simulates the structural behaviour using Finite Element Method (FEM).

\section{BIM maturity levels}

BIM models can be created with different levels of accuracy. During conversion between point cloud and geometrical model, several decisions can be made, in order to achieve different ranges of precision. The BIM literature refers to Level of Detail $(L o D)$ and to Level of Information ( $L o I)$. $L o D$ refers to the graphical elements of the model, whilst LoI refers to non-graphical information. ${ }^{2}$ Specifically, BSI PAS 1192:2-2013 [63] define LoD as "the level of detail should as a minimum represent the space allocation for the product's access space for maintenance, installation and replacement space in addition to its operational space. For example, the space required to turn on or turn off valves. [...] The "level of model detail" is the description of graphical content of models at each of the stages [...].", whilst LoI is defined as "[...] the description of non-graphical content of models at each of the stages". The BIM Task Group [64] defines the BIM levels of maturity, where the geometry is linked to its information holding capability. Four levels have been identified, defined as the following:

\footnotetext{
${ }^{1}$ https://www.iso.org/standard/51622.html; http://buildingsmart.org/ifc/.

${ }^{2}$ https://www.designingbuildings.co.uk/wiki/Level_of_detail_for_BIM.
}

- "Level 0: Unmanaged CAD, probably 2D, with paper [...] as the most likely data exchange mechanism."

- "Level 1: Managed CAD in 2D or 3D format [...] with a collaboration tool providing a common data environment, possibly some standard data structures and formats. [...]".

- "Level 2: Managed 3D environment held in separate "BIM(M) $)^{3 "}$ tools with attached data. [...] The approach may utilise 4D Programme data and 5D cost elements."

- "Level 3: Fully open process and data integration [...]. Managed by a collaborative model server. Could be regarded as $\mathrm{iBIM}^{4}$ or integrated $\mathrm{BIM}(\mathrm{M})$ potentially employing concurrent engineering processes."

Historic Scotland [5] "translates" this definition into a heritage-specific language:

- "Level 0: this could refer to a scenario where survey information is manually obtained on site using tapes and dumpy levels, drawn up using a CAD package in an unstructured format, and then communicated using paper plots."

- "Level 1: this could be a scenario where the site data is obtained digitally with an EDM (electronic distance meter, commonly known as "Total Station") and then transferred to a $2 \mathrm{D}$ or $3 \mathrm{D}$ CAD environment that uses standardised data structures."

- "Level 2: this could be a scenario where the site data is obtained digitally in an-inherently 3D format using a laser scanner, for instance, which is then transferred to a discipline-specific, standardised, parametric 3D modelling environment, but communicates and collaborates with other disciplines using industry-standard interface tools (e.g., IFCs). [...]."

It is worth noticing that no Level 3 is considered for heritage buildings. Note as well that, while the industry definitions of these levels include non-structural information such as cost, their heritage equivalents concentrate exclusively on the geometry of the building.

Tendencies in BIM for heritage are to create HBIM models that have a maturity level of $2,{ }^{5}$ i.e. which geometrical data have been derived through automatic procedures-such as laser scanning sessions-and the BIM model is created through parametric objects.

\footnotetext{
${ }^{3} \mathrm{BIM}(\mathrm{M})$ refers to management of "collection and exploitation of information across a project" [62].

4 iBIM stands for "Integrated Building Information Modelling" and it is a BIM model that includes "concurrent engineering processes" [62].

${ }^{5}$ http://bim4heritage.org/.
} 

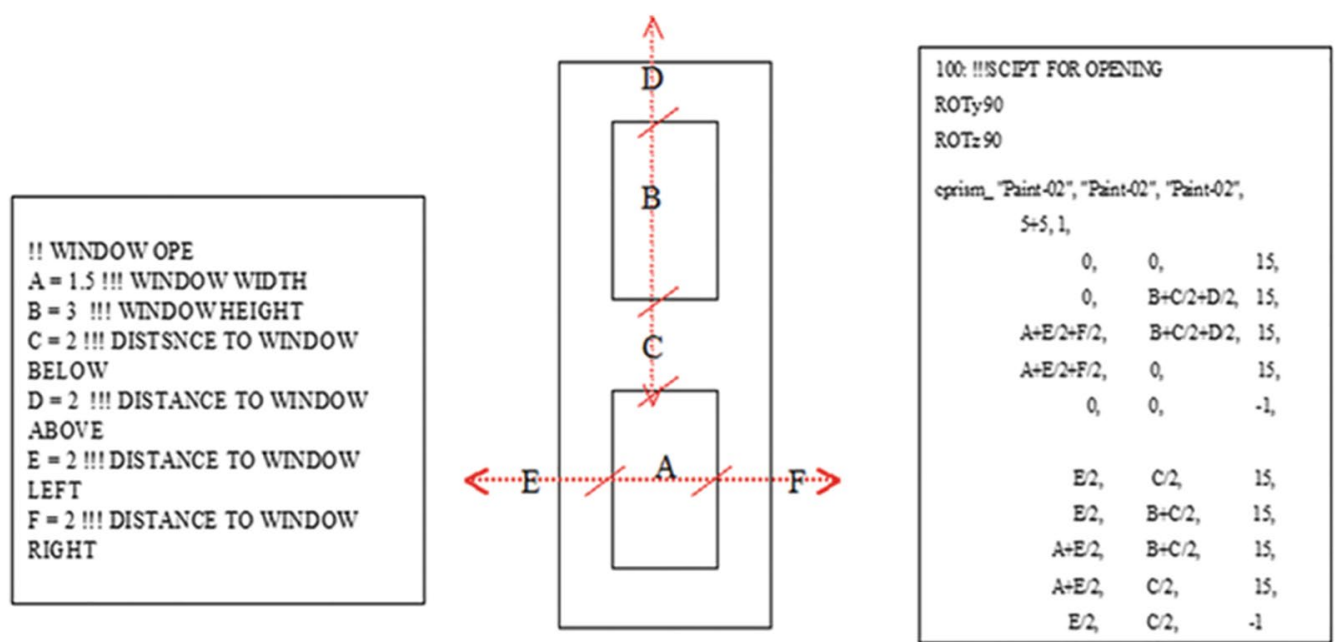

a

b

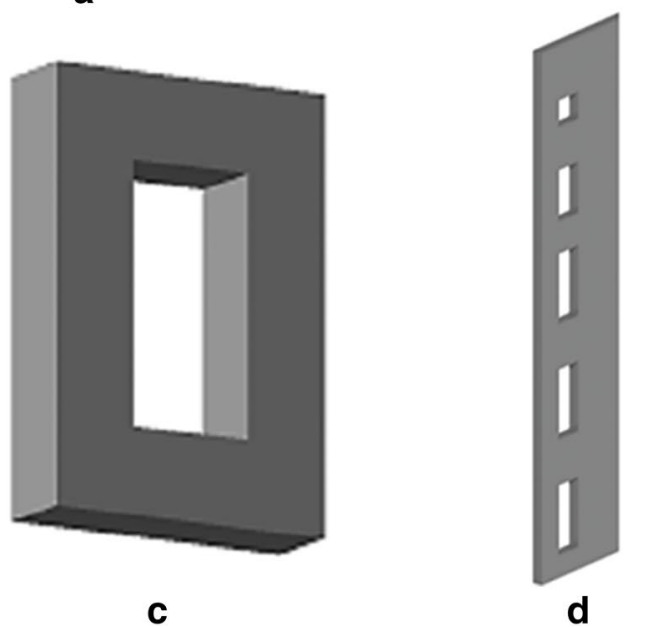

Fig. 1 Wall Façade as a GDL object. a Variables for opening, b GDL script, c single panel, d automated panels Source Dore and Murphy [1 1]. Courtesy of C. Dore and IEEE

\section{Modelling: smart object libraries}

The modelling phase is where all the task previously explained culminates. BIM software allows the digitisation of buildings, providing geometrical, architectural and material information [3, 7]. Moreover, environmental data and energy performance analysis can be added through dedicated plug-ins. BIM models are not just drawings, but they hold semantic information [65], with parametric smart object libraries, such as the previously mentioned HBIM [9-12, 18, 19, 66] Parametric elements are digital objects that can be modified/updated when needed $[7,14,19,20,22]$. They are modelled in Geometric Descriptive Language $(G D L)[9,12,18,19,66]$, which means that are defined by parameters (See Fig. 1). Figure 1 illustrates the potential to automate library parts based on numeric data extracted from the point cloud.
Detail $a$ represents the variables that define the location of an opening these are illustrated in the vector diagram in the centre. The variable consists of the size of the opening and the distance of the opening from other objects, in this case other openings. The GDL script is illustrated in detail $b$, which generates the single panel in detail $c$. The panel can then be repeated to form the full panel in detail $d$. The use of GDL scripts are an example of building code-based library objects (as opposed to graphic based) which include as many geometric parameters as possible allowing for the objects to be revised to comply with different scenarios and plotted from point cloud or other survey data.

$H B I M$ is commonly intended as a specific library of parametric smart objects [21, 62]. However, when it was created in 2009 [9-12, 18, 19, 66], the authors themselves 
described it as a specific BIM process for built heritage, which consists of three main phases:

1. Data collection, carried out integrating TLS and Digital Photogrammetry, as it is recommended to reduce error probability [67];

2. Data processing, performed through noise cleaning, points re-sampling, and point cloud registration;

3. Modelling phase, i.e. polygonal surface meshing and texturing. A parametric library is created, modelling the elements by the combination of simple geometrical shapes, where parameters are decided before shaping.

HBIM should be intended as procedural modelling [10-12, 14, 19, 52, 68]. Specifically, it creates objects following procedural modelling rules, based on shape grammars-shape grammars are 3D elements automatically created from a basic "vocabulary" following specific "production rules" [10, 12, 19, 52, 66]. These elements can then be adapted case-by-case. They were firstly introduced during the 70 s by Stiny and Gips $[12,19,49,52$, 69].

$H B I M$ processes are continuously evolving. Latest studies attempt to automate the $H B I M$ process, creating an accessible and modifiable parametric library of pre-defined digital objects that can represent a diversity of actual objects. This, for example, has been attempted with the architectural grammar of classical Europe and Ireland in the seventeenth and eighteenth century [19]. This approach may be argued to be at odds with the nature of heritage: while historic objects and building components are valued for their individuality, parametric libraries implicitly assume that they can be reproduced digitally with generalisable digital objects. The possibilities and limitations of parametric libraries are under active research. Dore and Murphy [11] propose an integration of $H B I M$ library using $A D E$, a City $G M L$ extension (GML stands for Generative Modelling Language). ADE enriches the existing semantic class in CityGML, making library objects more suitable for describing built heritage. Indeed, $A D E$ divides the model into sub-elements that are enriched with attributes and external references. External references can be databases or web resources, containing heritage-specific information such as historical data, chronological phases, different layers, etc. Efforts like $A D E$ have developed the mainstream $H B I M$ knowledge. However, many researchers agree on the fact that-in general-further research is needed $[11,16,27$, $30,62]$ to simplify essential tasks, - and specificallyespecially parametric library creation, which is still manual $[9,27]$ and time-consuming $[7,62]$.
JHBIM is an HBIM extension designed for Old Jeddah built heritage $[4,8,24]$. Its purpose is to produce a parametric smart object library that can be used both for buildings in Jeddah (specific materials, common material degradations, local construction techniques) and for heritage buildings in general. JHBIM study can help in management performance and in decision-making for conservation interventions [4], and it practically demonstrates that BIM technology is possible for heritage buildings. JHBIM has provided a complete library of Jeddah-specific smart objects, which are already linked to graphics, tables and metadata. They can be modified and fitted into any BIM model $[4,8,24]$.

\section{Metadata handling}

Building Information Modellings most powerful feature is considered to be integration of data $[7,16]$. Creating a BIM parametric 3D model means that every modelled object is linked to a table/spreadsheet, where its parameters and its characteristics are displayed $[4,7,25]$. The main problem is metadata handling: these tables show specific parameters, but metadata-such as historical documentation, photographs, texts, etc. are missing, despite being strongly required in heritage field [34, $35,70,71]$. Indeed, previous records, i.e. metadata, help the analysis tasks, as they support material recognition, degradation prevention and adequate interventions. Additionally, beyond the survey phase accuracy, lack of historical information strongly affects reliability [17, 72].

Currently, external database content must be manually copy-pasted inside BIM spreadsheets. This means that if any external databases change their information, BIM spreadsheet will not be synchronised, i.e. BIM model will not be updated, and it needs to be changed manually [20]. Some authors $[50,73]$ have proposed the use of videogame engines to produce a virtual tour into the 3D model, and metadata are provided when clicking on the interested object. Others [56, 74] use Semantic Web Platform $(S W P)$, where 3D models are displayed and linked to a PHP (PHP: Hypertext Preprocessor) page where texts, documents, photographs and graphics are embedded.

A few attempts [75] have been made to use BIM to describe thermal behaviour and to monitor energetic parameters, such as temperature, relative humidity, etc. in built heritage. Unfortunately, thermo-hygrometric models are still confined in BIM for new buildings [2], even if variation of these parameters are often the main cause of materials' degradation [32, 40, 76, 77]. A BIM model of a heritage building featuring environmental parameters could play an important role in supporting risk assessment and decision-making for interventions and for forecasting possible future degradations [32, 77, 78]. 
Table 1 BIM maturity levels supporting heritage-specific metadata

\begin{tabular}{|c|c|c|c|}
\hline Heritage-specific metadata & BIM level 0 & BIM level 1 & BIM level 2 \\
\hline Archival photos & & 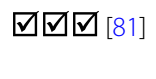 & 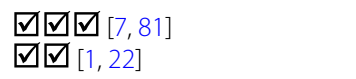 \\
\hline Archival texts/docs & & 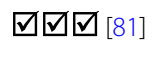 & 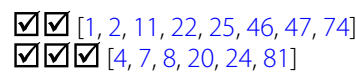 \\
\hline Historical layers & & 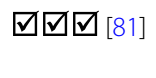 & $\begin{array}{l}\square \square[1,2,11,22,25,46,47,74] \\
\square \square \square[4,7,8,20,24,81]\end{array}$ \\
\hline Previous interventions & & & $\begin{array}{l}\text { 四 }[1,2,11,22,25,46,47,74] \\
\text { 田 }[4,7,8,20,24]\end{array}$ \\
\hline Degradation patterns & & & $\begin{array}{l}\text { चవ [22] } \\
\square \square \square[4,8,20,24]\end{array}$ \\
\hline Material properties and characterisation & & & $\begin{array}{l}\text { 四 }[11,22,25] \\
\square \square \square[4,7-9,19,20,24]\end{array}$ \\
\hline Environmental data & & & $\square[2]$ \\
\hline Predictions of degradation development & & & $\nabla$ \\
\hline Architectural style and grammar & & & 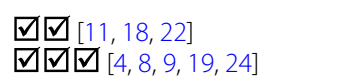 \\
\hline
\end{tabular}

$\checkmark \square \square$ : done successfully with BIM platforms. This means that integration of heritage-specific metadata into BIM models has been done successfully using BIM platforms, and it is possible to reference these researches

$\square \square$ : done successfully with integration of external-BIM-environment platforms. This means that integration of heritage-specific metadata has been done successfully using software/platforms that are not usually considered BIM

$\checkmark$ : never done, but potentially feasible. This means that integration of heritage-specific metadata has never been attempted, but it reasonable to suppose that it could be done given the available technologies

Until now, there have been a few attempts to represent condition (which could be defined as an assessment of the state of conservation of an object in view of its desired uses) in heritage field with BIM. Essentially, there have been hypothetical reconstructions of ruins/damaged buildings [28, 46, 56, 79], and stratigraphic depictions $[27,50]$. It is evident that representing condition is a difficult task, as professionals' interpretational skills play a master role $[23,56,72,74,79,80]$. In practice, the outcome of condition assessments strongly depends on the professionals' experience and rigorousness.

The above-mentioned experiments are certainly effective, even if they do not completely solve BIM integration problem, as conversions from volumetric objects (i.e. simple digital masses) to "smart" (i.e. parametric) ones are complicated without strong IT background. However, they represent an important achievement and a potential starting point for further research [6].

To brief, typical metadata for heritage buildings are:

- Archival photographs $[1,5,22,81]$;

- Archival research texts/documents, including history of the building, its interventions and previous reports $[1,2,4,5,7,8,11,20,22,24-26,46,47,74,81]$;

- Condition reports, including survey photographs and degradation patterns $[4,5,8,20,22,24]$;

- Material characterisation [4, 5, 7-9, 19, 20, 22, 2426];
- Environmental data $[2,5]$;

- Architectural data [4, 5, 8, 9, 18, 19, 22, 24]; and

- All other data describing the heritage building.

All the procedures above described can be considered part of heritage science, as defined by The National Heritage Science Forum [82]: "Heritage science plays a vital part in understanding and preserving [...] [our] heritage and, equally importantly, in giving us fuller understanding and appreciation of its significance." Indeed, all metadata that could potentially be embedded to BIM would have the primary purpose of supporting an increased understanding of heritage buildings. As shown above, many researchers have proposed different ways to include several types of information in a BIM environment.

\section{Case studies}

Table 1 above shows the relationship between heritagespecific metadata and BIM maturity levels. Its main aim is to present how active research is carried out about embedding metadata, and which techniques are used, relating them to the maturity levels as defined by Historic Scotland (cfr. "BIM maturity levels" section). Specifically, it illustrates what kind of heritage-specific metadata has been included in which BIM maturity level, and if it has been done with a BIM-related method, or with a methodology external to the BIM environment. Notice that BIM level 3 has not been included in this table, as it has 
not been defined for built heritage (yet) (cfr. "BIM maturity levels" section). The papers reviewed under this section are clearly not the only ones existing, but they are a major number and can be considered representative of the current trends. Results of this analysis show that combination between Laser Scanning and Digital Photogrammetry is currently one of the most used techniques, whilst metadata are added to 3D models chiefly through spreadsheets, images and texts. Parametric smart object libraries are created with $G D L$ scripts, following the shape grammars procedural modelling as in Murphy's HBIM and Baik's JHBIM. However, there seems not to exist any attempt to insert degradation pattern predictions yet.

For the Batawa Project, Fai et al. [81] managed to include archival photo, previous reports and historical layers into a mixed-level BIM model, which was obtained through laser scanning (BIM level 2) and through existing digital files (that could be considered BIM level 1). Through Navisworks they also managed to simulate the timeline of the different renovation phases the building has been subjected to. This research is an attempt of embedding both quantitative and intangible data in the virtual model, as they are both characterising heritage buildings.

Saygi et al. [22] include almost all heritage-specific metadata in their BIM level 2 model of the Kurşunlu Khan in Turkey, to highlight the importance of metadata for conservation and management processes. Their approach is an integration of BIM-related methods/ software-specifically, they use Autodesk Revit-and GIS. Similarly, Oreni et al. [20] (see Fig. 2) produce a BIM level 2 model through laser scanning, and manage to include heritage-specific metadata using two different BIM platform (Autodesk Revit and GraphiSoft ArchiCAD) and comparing them. This research focuses on the reconstruction of vaults and floor in the Soldi Palace in Cremona, Italy. The authors conducted a deep analysis and survey on the stratigraphy of the building, and they emphasise the importance of the knowledge of historical layers and construction techniques in heritage buildings, specifically for structural elements. They also underline the urgency for a common vocabulary of semantic objects, particularly needed for preventive conservation practices.

Chenaux et al. [9] (see Fig. 3) carry out an experiment to have evaluated a virtual learning environment tool and a surveying process conducted by students. Using the survey data produced by the students, a BIM level 2 model is created, using laser scanning outputs, CAD drawing and photographs available online on the CyArk database. ${ }^{6}$ The embedding of metadata has been obtained through modelling of architectural elements in $G D L$, obtaining parametric objects organised into libraries and referenced inside the models. They used BIM software GraphiSoft ArchiCAD. Through three different case studies, they manage to produce 3D models where information is embedded in different formats. Specifically for the National Monument Edinburgh case study, data were inserted as it follows (this list is not exhaustive):

- Floor plans are directly derived from survey;

- Rectified images detail elevations and cross sections, and reference the location of library objects;

- Locations of library objects are expressed in coordinates, which are stored into spreadsheets.

These experiments show an innovative way of embedding metadata using survey outputs, existing data and existing database.

Similarly, Murphy et al. [19], produce a BIM level 2 model, using integration of laser scanning and photogrammetry, and modelling with BIM software GraphiSoft ArchiCAD as well. Dore and Murphy [11] try again to improve $H B I M$ ad metadata insertion, this time by uploading the finished BIM model to an international GIS platform called CityGML (i.e. external-BIM platform), in order to facilitate management and further analysis. On the other hand, Murphy et al. [18], in one of their first experiments, use laser scanning to produce a BIM level 2 model. Architectural elements are modelled using a range of different software, from point clouds editors to meshing tools. Similar to Murphy's HBIM is Baik's JHBIM [4, 8, 24], as previously stated. JHBIM methodology produces a BIM level 2 model through laser scanning, using Autodesk Revit as the main BIM platform. It includes almost all metadata such as history, degradation patterns, material characterisation and-of coursearchitectural grammar (see Fig. 4). Main objective of this research is the creation of an Old Jeddah-specific object library, focusing on the Al-Balad district, in order to facilitate future digitisations. The authors point out the potential use of JHBIM in future applications, specifically related to GIS mapping, reconstructions, documentation, education, dissemination and management support.

In the same way, Ángulo Fornos [1] produces a BIM level 2 model for his case study Casa de Hylas in Spain, as shown in Fig. 5. He uses-again-laser scanning to survey the building. Modelling took place using BIM platform Autodesk AutoCAD Architecture, whilst 


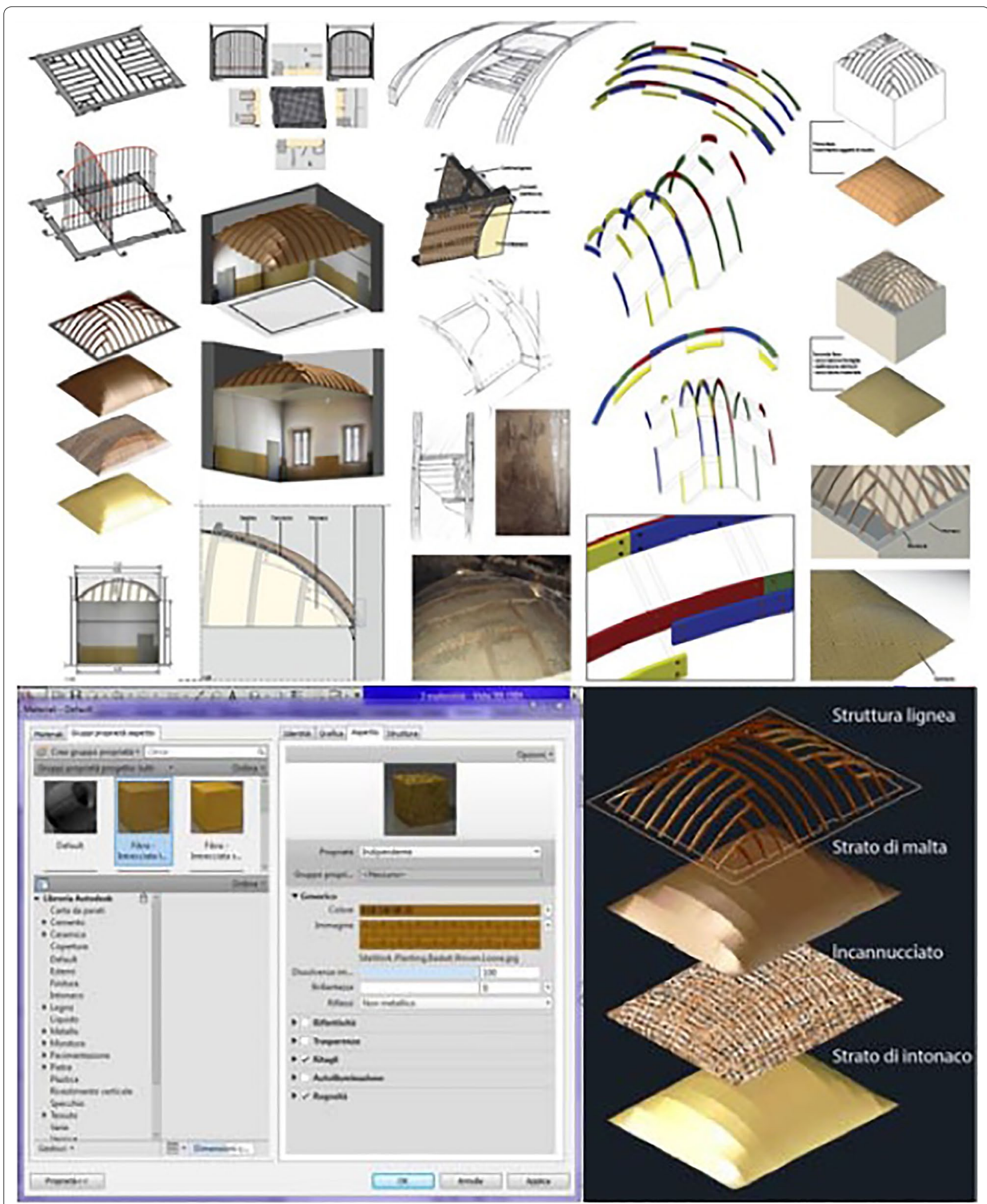

Fig. 2 HBIM (@Autodesk Revit) of wooden vault in Soldi Palace in Cremona (Italy): 3D elements modelling process using laser scanner point clouds and hands on measurements. Information on materials, their stratigraphy and geometrical data of architectural elements are indicated in the database. Source Oreni et al. [20]. Courtesy of D. Oreni 


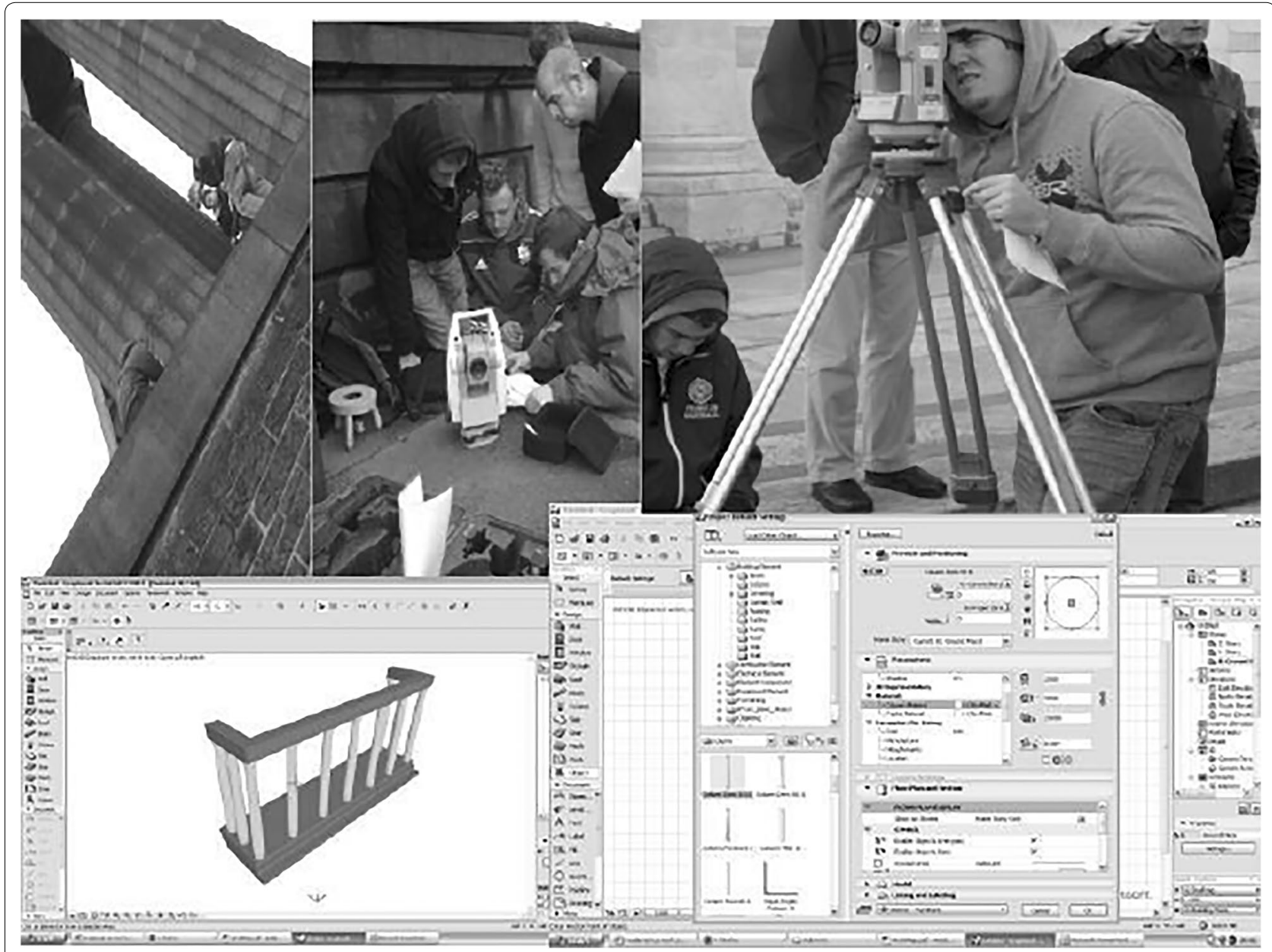

Fig. 3 Students on-site surveying and HBIM model. Source Chenaux et al. [9]. Courtesy of M. Murphy and A. Čepek—Geoinformatics CTU FCE 2011

metadata-such as archival texts/photographs, historical layers and past interventions-were inserted using Microsoft ODBC and OLE DB. This research brings attention to the current tendency of data loss and data replication, as different professionals are often involved in the same conservation projects. Its aim is therefore to produce a unique tool, based on a virtual model, that is capable to hold and display all the needed informationand ensure accessibility.

Arayici [2] uses as well laser scanning to digitise his case study in East Manchester. Point cloud editing and meshing produce an output that can then be used to create a CAD model. The CAD model is transferred to BIM and information is stored in the Triforma (a MicroStation platform, i.e. BIM-external) library. The actual BIM model is reached as soon as the elements are turned into IFC objects. Arayici suggests also the possibility of integrating BIM models with environmental data. In his paper, he does not specify if he has done it, but it seems reasonable to think that it is feasible/it will be possible in the near future.

Worrell [7] analyses different BIM software and methodologies to produce a BIM level 3 model. She finally produces it, laser scanning during the survey phase and using BIM platform Autodesk Revit for the modelling. She also manages to add some metadata and visualise it through another BIM platform-Autodesk Navisworks. This research introduces to the USA's current trends, which are following Europe's ones. Cost is also mentioned: whilst the benefits of using BIM in conservation are recognised, the issue of the cost is presented as a factor that can be a barrier to small trusts/charities or enterprises.

All the examples cited above, show that integration between laser scanning and photogrammetry is a typical way to produce a textured point cloud that will be converted afterwards into a BIM level 2 model. It is then common practice to work within a BIM-environment, using Revit, ArchiCAD, etc., and embedding metadata 

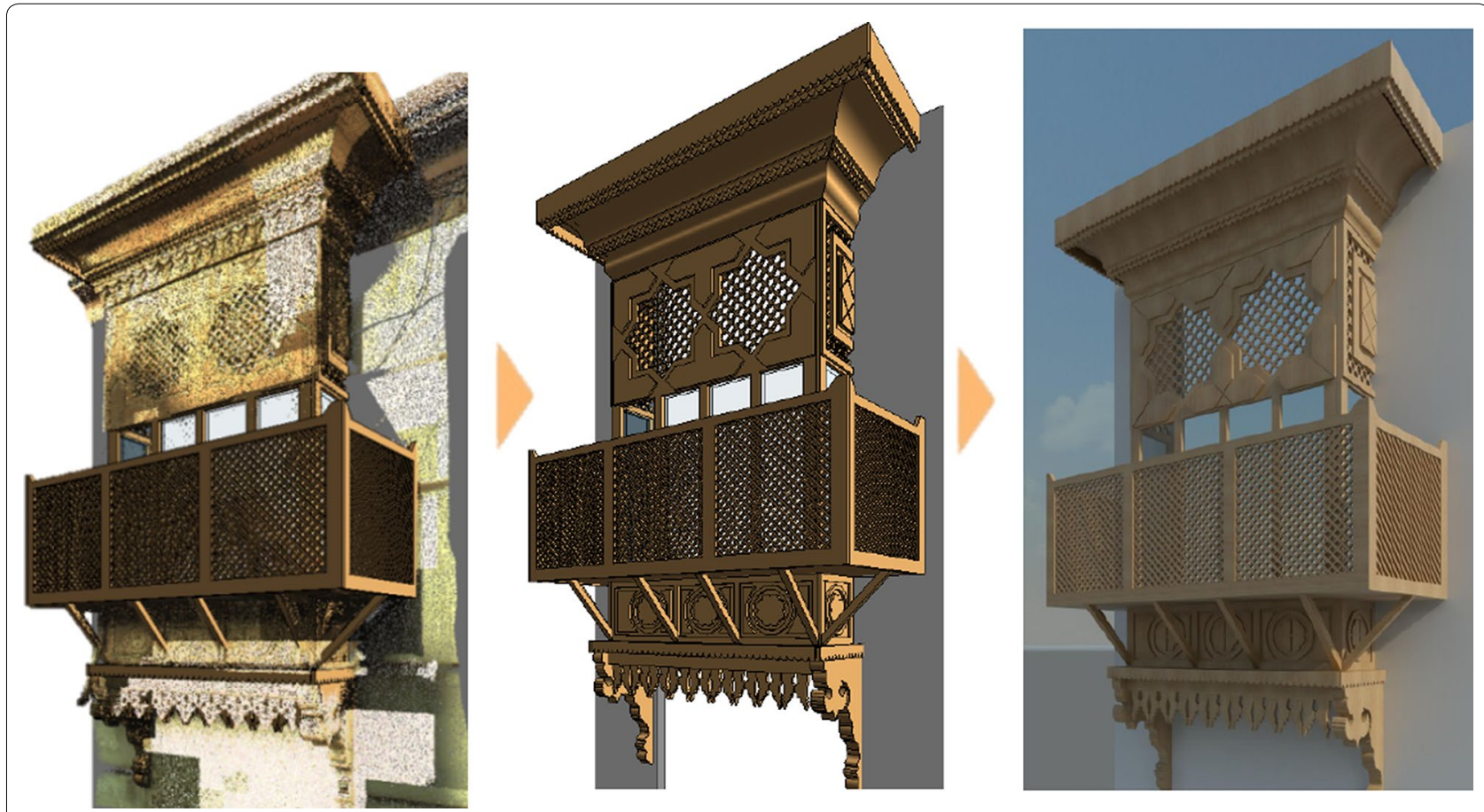

Fig. 4 Steps of the Roshan modelling. Source Baik et al. [4]. Courtesy of A. Baik

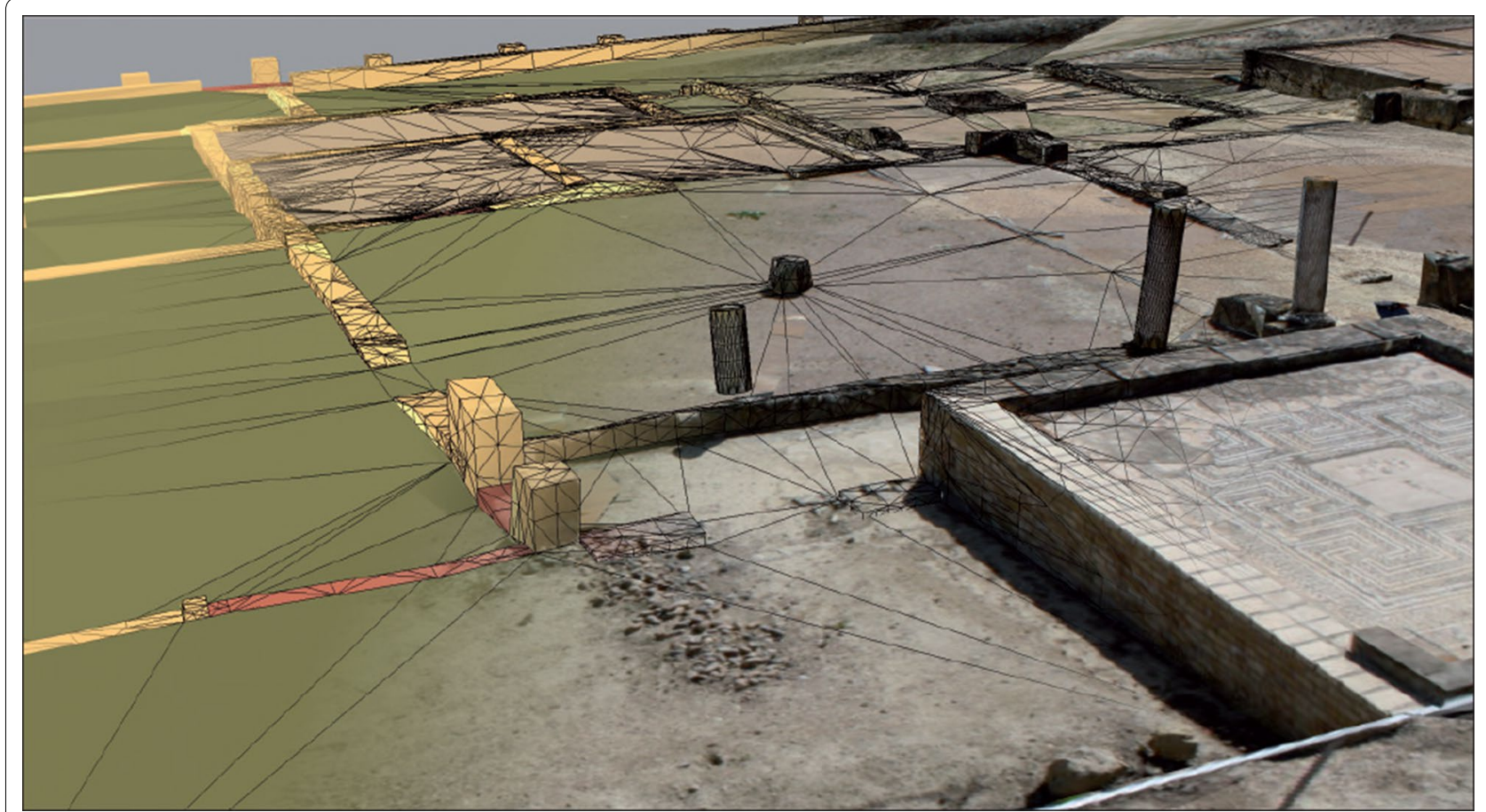

Fig. 5 View of the textured model from North-West. Source Ángulo Fornos [1]. Courtesy of S. A. Llamas—Arqueología de la Arquitectura 
through either external database or BIM spreadsheets/ other BIM software. Table 1 cites works done by other researchers as well. Discussion of these further studies is omitted for brevity, as results are comparable to the ones examined above. Table 1 also illustrates that BIM level 0 has been largely surpassed in the heritage sector. Finally, Table 1 shows that-to the authors' knowledge-there has not been any attempt to include any predictions of degradation patterns so far. This is logical, as inclusion of environmental parameters is still in its initial phase of research-and weathering forecasts are possible only having a clear understanding of the environment.

Concluding, Table 1 and the consequent discussion show that research about how to embed metadata is active and mostly successful. However, inclusion of environmental parameters-including monitoring and forecasting-has just started to be studied, and developments are hopefully expected to happen in the near future.

\section{Future work and conclusions}

The present piece summarises the main findings in the current literature concerning BIM process for heritage buildings. Potentially, BIM is able to support the information used for conservation and in heritage science projects; however, technology has not yet been developed to a level to permit it. Except for some noteworthy examples, nowadays it is common practice to use BIM in the development of new buildings, but there are some issues with existing buildings.

What follows is a list of the various technological aspects of BIM and the research issues that emerge in relation to heritage science:

- Survey techniques: different methods are in use, from traditional approaches to advanced automated methods such as TLS integrated with GIS, Digital Photogrammetry and UAV. Through these methods, a cloud of points representing the digital format of the real building is obtained. A common problem is the optimisation of the conversion from point clouds to 3D models. The exportation step is still difficult and time-consuming, even if there have been some attempts at automation.

- Point clouds: the latest survey techniques for built heritage present data into point cloud format, which has the capacity of capturing very fine details but, at the same time, the conversion to a 3D model is still intricate and time-consuming. Further research is needed in order to identify which $L o D$ is required to enable different tasks (analysis, monitoring, recording of condition).

- Parametric smart object libraries are an attempt to square the circle: to create generalizable objects that can represent individual features of historic buildings. Their advantage is that they contain objects that are virtual format of existing constructive elements, and need to be modelled just once. Their parametric nature is of great advantage as they can be modified and updated as needed, e.g. when there has been a maintenance, a process of change, a new discovery, etc. Parametric libraries can contain different kind of objects: constructive elements, architecture-language components, constructive techniques, etc. There are two main libraries so far: $H B I M$ and JHBIM, which is a specific $H B I M$ extension for Old Jeddah. These libraries have been created following procedural modelling rules, coded with $G D L$ scripts, in order to automatically create elements that are based on shape grammars. Nevertheless, using parametric smart objects libraries can be slightly restrictive, since if a specific architectural style is not present in parametric libraries, they need to be manually modified. As new libraries for historical styles are developed, research will be needed in order to identify the limitations of this approach.

- Unified visualisation between 3D model and metadata: BIM's most advantageous feature for heritage science is perhaps its ability to link 3D models to metadata. Through this paper, a table has been created to detail the relationships between existing literature and BIM maturity levels, in order to show how researchers are currently dealing with the metadata-embedding issue. Types of metadata are listed, as well as ways in which researchers have managed to embed them into the 3D models. So far, this connection has been made through tables/spreadsheets, database and $P H P$ pages. There have also been interesting experiences in the use of videogame engines to perform a virtual tour of a 3D model populated with related metadata. However, research is urgently needed in the development of a heritage-specific technology that can sustain and display heritage science information; that is, historical data, condition, environmental parameters, risks to the materials and their forecasts.

From the achieved findings and from the made remarks, it comes out that further research is needed. Specifically, future work should focus on:

- How to (visually) unify 3D smart models and metadata;

- How to automate importation process (from points cloud to 3D smart model).

- How to include condition, risks, environmental parameters and forecasts. 


\section{Abbreviations}

3D: three dimensions; AEC: Architecture, Engineering and Construction; BIM: Building Information Modelling; CAD: Computer Aided Design; CFD: Computational Fluid Dynamics; FEM: Finite Element Method; GDL: Geometric Descriptive Language; GIS: Geographic Information System; GML: Generative Modelling Language; HBIM: Historic Building Information Modelling; IFC: Industry Foundation Classes; ISH: Institute for Sustainable Heritage; IT: Information Technology; JHBIM: Jeddah Historic Building Information Modelling; LoD: Level of Detail; Lol: Level of Information; NURBS: Non Uniform Rational Basis Splines; PHP: Hypertext Pre-processor; SfM: Structure from Motion; SWP Semantic Web Platform; TLS: Terrestrial Laser Scanner; UAV: Unmanned Aerial Vehicle.

\section{Authors' contributions}

DPP has written the main body and the conclusions. JG-B has written the abstract and the introduction with DPP, and has repeatedly reviewed the whole text, making precious comments and suggestions. PB, JB and JS have reviewed the whole text and have made comments and suggestions to improve it. All authors read and approved the final manuscript.

\section{Author details}

${ }^{1}$ The Bartlett School of Environment, Energy and Resources, Institute for Sustainable Heritage, University College London, Central House, 14 Uppe Woburn Place, London WC1H ONN, UK. ${ }^{2}$ Department of Civil, Environmental \& Geomatic Engineering, Faculty of Engineering Science, University College London, Chadwick Building, Gower Street, London WC1E 6BT, UK. ${ }^{3}$ Historic England, 37 Tanner Row, York YO1 6WP, UK. ${ }^{4}$ Point 2 Surveyors, 17 Slingsby Place, London WC2E 9AB, UK.

\section{Acknowledgements}

The authors would like to thank David Thickett, English Heritage, for the precious comments and suggestions made. Thanks also to Julia Schütz of ScanLAB Projects for helping with scanning and point cloud post-processing. Thanks to the Institute for Sustainable Heritage (ISH) of University College London (UCL) for the facilities and the support provided. We would also like to thank SEAHA EPSRC doctoral training centre.

\section{Competing interests}

The authors declare that they have no competing interests.

\section{Availability of data and materials}

Not applicable.

\section{Consent for publication}

Not applicable.

Ethics approval and consent to participate Not applicable.

\section{Funding}

This paper is part of Danae P Pocobelli's Ph.D. The above-mentioned Ph.D. is funded by SEAHA, an EPSRC doctoral training centre.

\section{Publisher's Note}

Springer Nature remains neutral with regard to jurisdictional claims in published maps and institutional affiliations.

Received: 27 July 2017 Accepted: 9 April 2018

Published online: 16 May 2018

\section{References}

1. Angulo Fornos R. Construcción de la base gráfica para un sistema de información y gestión del patrimonio arquitectónico: Casa de Hylas. Arqueol la Arquit. 2013;0(9):11-25. http://arqarqt.revistas.csic.es/index .php/arqarqt/article/view/138/132. https://doi.org/10.3989/arqar qt.2012.10005. Accessed 3 Nov 2015.
2. Arayici Y. Towards Building Information Modelling for existing structures. Struct Surv. 2008;26(3):210-22. http://www.emeraldinsight.com/doi/ abs/10.1108/S1479-3563\%282012\%29000012B007. Accessed 2 Nov 2015.

3. Azhar S, Khalfan M, Maqsood T. Building Information Modelling (BIM): now and beyond. Australas J Constr Econ Build. 2012;12(4):15. http:// epress.lib.uts.edu.au/journals/index.php/AJCEB/article/view/3032/3245. https://doi.org/10.5130/AJCEB.v12i4.3032.

4. Baik A, Alitany A, Boehm J, Robson S. Jeddah historical Building Information Modelling "JHBIM" object library. ISPRS Ann Photogramm Remote Sens Spat Inf Sci. Vol. 2(5), 2014 ISPRS Tech Comm V Symp 23-25 June 2014, Riva del Garda, Italy. 2014:2(5):41-7. http://www.isprs-ann-photo gramm-remote-sens-spatial-inf-sci.net/II-5/41/2014/. Accessed 2 Nov 2015.

5. Maxwell I. Integrating digital technologies in support of historic Building Information Modelling: Bim4conservation (HBIM). 2014. http://www. cotac.org.uk/docs/COTAC-HBIM-Report-Final-A-21-April-2014-2-small.pdf. Accessed 10 Jan 2017

6. Yen YN, Weng KH, Huang HY. Study on information management for the conservation of traditional Chinese Architectural Heritage-3D modelling and metadata representation. ISPRS Ann Photogramm Remote Sens Spat Inf Sci. 2013;2(5)/W1:331-6. http://www.isprs-ann-photogramm-remot e-sens-spatial-inf-sci.net/Il-5-W1/331/2013/. Accessed 15 Nov 2015.

7. Worrell LL. Building information modeling (BIM): the untapped potential for preservation documentation and management. Clemson University; 2015.

8. Baik A, Boehm J, Robson S. Jeddah historical building information modeling "JHBIM" Old Jeddah-Saudi Arabia. Int Arch Photogramm Remote Sens Spat Inf Sci. 2013;40(5W2):73-8. http://www.scopus.com/inward/ record.url?eid $=2-s 2.0-84924289373 \&$ partner|D $=40 \& m d 5=8 \mathrm{c} 86167738$ $7 f c a 1$ ecba46c9b02343a33. Accessed 2 Nov 2015.

9. Chenaux A, Murphy M, Keenaghan G, Jenkins J, McGovern E, Pavia S. Combining a virtual learning tool and onsite study visits of four conservation sites in Europe. Geoinformatics FCE CTU. 2011;6(0):157-69. https:// ojs.cvut.cz/ojs/index.php/gi/article/view/2656. https://doi.org/10.14311/ gi.6.21. Accessed 1 Nov 2015.

10. Dore C, Murphy M, McCarthy S, Brechin F, Casidy C, Dirix E. Structural simulations and conservation analysis-historic building information model (HBIM). ISPRS Int Arch Photogramm Remote Sens Spat Inf Sci. 2015;40(5)/W4(5W4):351-7. http://www.int-arch-photogramm-remot e-sens-spatial-inf-sci.net/XL-5-W4/351/2015/. Accessed 6 Nov 2015.

11. Dore C, Murphy M. Integration of historic building information modeling (HBIM) and 3D GIS for recording and managing cultural heritage sites. In: 2012 18th International conference on virtual systems and multimedia. IEEE. 2012. p. 369-76. http://arrow.dit.ie/beschreccon/71/. https://doi. org/10.1109/vsmm.2012.6365947. Accessed 3 Nov 2015.

12. Dore C, Murphy M. Semi-automatic modelling of building façades with shape grammars using historic Building Information Modelling. Proc Int Arch Photogramm Remote Sens Spat Inf Sci. 2013;40:57-64.

13. Fai S, Filippi M, Paliaga S. Parametric modelling (BIM) for the documentation of vernacular construction methods: a BIM model for the commissariat building, Ottawa, Canada. ISPRS Ann Photogramm Remote Sens Spat Inf Sci. 2013;2(5)/W1(5):115-20. http://adsabs.harvard.edu/abs/20131 SPAn.II5a.115F. Accessed 10 Nov 2015.

14. Fai S, Sydor M. Building Information Modelling and the documentation of architectural heritage: between the "typical" and the "specific". In: 2013 digital heritage international congress (DigitalHeritage). IEEE; 2013. p. 731-4. http://ieeexplore.ieee.org/xpls/abs_all.jsp?arnumber $=6743828$. Accessed 10 Nov 2015

15. Garagnani S, Manferdini AM. Parametric accuracy : building information modeling process applied to the cultural heritage preservation. ISPRS Int Arch Photogramm Remote Sens Spat Inf Sci. 2013;40(5)/W1:87-92. http://www.int-arch-photogramm-remote-sens-spatial-inf-sci.net/XL5-W1/87/2013/. Accessed 10 Nov 2015.

16. Logothetis S, Delinasiou A, Stylianidis E. Building Information Modelling for cultural heritage: a review. ISPRS Ann Photogramm Remote Sens Spat Inf Sci. 2015;2(5)/W3:177-83. http://www.isprs-ann-photogramm-remot e-sens-spatial-inf-sci.net/II-5-W3/177/2015/. Accessed 11 Nov 2015.

17. Di Mascio D, Wang X. Building Information Modelling (BIM)-supported cooperative design in sustainable renovation projects. In: Cooperative design, visualization, and engineering SE-30. 2013. p. 205-12. http:// dx.doi.org/10.1007/978-3-642-40840-3_30. Accessed 2 Nov 2015. 
18. Murphy M, McGovern E, Pavia S. Historic Building Information Modelling (HBIM). Struct Surv. 2009;27(4):311-27. http://www.emeraldinsight.com/ doi/book/10.1108/S1479-3563\%282012\%2912_Part_B. Accessed 13 Nov 2015.

19. Murphy M, McGovern E, Pavia S. Historic Building Information Modelling - adding intelligence to laser and image based surveys of European classical architecture. ISPRS J Photogramm Remote Sens. 2013;76:89-102. https://doi.org/10.1016/j.isprsjprs.2012.11.006.

20. Oreni D, Brumana R, Georgopoulos A, Cuca B. HBIM for conservation and management of built heritage : towards a library of vaults and wooden bean floors. ISPRS Ann Photogramm Remote Sens Spat Inf Sci. 2013;2(5)/ W1:215-21. http://www.isprs-ann-photogramm-remote-sens-spati al-inf-sci.net/II-5-W1/215/2013/. https://doi.org/10.5194/isprsannals-ii5-w1-215-2013. Accessed 13 Nov 2015.

21. Oreni D. From 3D content models to HBIM for conservation and management of built heritage. In: The 13th international conference on computational science and its applications. 2013. p. 344-57. http://link.springer. com/10.1007/978-3-642-39649-6_25.

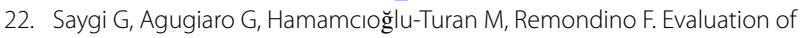
GIS and BIM roles for the information management of historical buildings. ISPRS Ann Photogramm Remote Sens Spat Inf Sci. 2013;2:283-8. http:// adsabs.harvard.edu/abs/2013ISPAn.II5a.283S. Accessed 14 Nov 2015.

23. Volk R, Stengel J, Schultmann F. Building Information Modelling (BIM) for existing buildings-literature review and future needs. Autom Constr. 2014;38:109-27. https://doi.org/10.1016/j.autcon.2013.10.023.

24. Baik A, Yaagoubi R, Boehm J. Integration of Jeddah historical BIM and 3D GIS for documentation and restoration of historical monument. ISPRS Int Arch Photogramm Remote Sens Spat Inf Sci. 2015;40(5)/W7(5W7):29-34. http://www.int-arch-photogramm-remote-sens-spatial-inf-sci.net/XL5-W7/29/2015/. Accessed 2 Nov 2015.

25. Columbu S, Verdiani G. Digital survey and material analysis strategies for documenting, monitoring and study the Romanesque churches in Sardinia, Italy. In: Ioannides M, Magnenat-Thalmann N, Fink E, Žarnić R, Yen A-Y, Quak E, editors. Cultural heritage: documentation, preservation, and protection: 5th international conference, EuroMed 2014, Limassol, Cyprus, November 3-8, 2014. Cham: Springer International Publishing; 2014. p. 446-53 (Lecture Notes in Computer Science; vol. 8740). http:// link.springer.com/10.1007/978-3-319-13695-0. Accessed 4 Nov 2015.

26. Ma Y-P, Hsu CC, Lin M-C, Tsai Z-W, Chen J-Y. Parametric Workflow (BIM) for the repair construction of traditional historic architecture in Taiwan. ISPRS Int Arch Photogramm Remote Sens Spat Inf Sci. 2015;40(5)/ W7(5W7):315-22. http://www.int-arch-photogramm-remote-sens-spati al-inf-sci.net/XL-5-W7/315/2015/. Accessed 28 Oct 2017.

27. Brumana R, Oreni D, Raimondi A, Georgopoulos A, Bregianni A. From survey to HBIM for documentation, dissemination and management of built heritage: the case study of St. Maria in Scaria d'Intelvi. In: Proceedings of the DigitalHeritage 2013-federating the 19th Int'I VSMM, 10th Eurographics GCH, and 2nd UNESCO Memory of the World Conferences, Plus Special Sessions from CAA, Arqueologica 20 et al. IEEE; 2013. p. 497-504. http://ieeexplore.ieee.org/document/6743789/. Accessed 2 Nov 2015.

28. Ludwig M, Herbst G, Rieke-Zapp D, Rosenbauer R, Rutishauser S, Zellweger $\mathrm{A}$. The advantages of parametric modeling for the reconstruction of historic buildings. The example of the in war destroyed church of St. Catherine (Katharinenkirche) in Nuremberg. ISPRS Int Arch Photogramm Remote Sens Spat Inf Sci. 2013:40(5)/W1:161-5. http://www.int-archphotogramm-remote-sens-spatial-inf-sci.net/XL-5-W1/161/2013/. Accessed 11 Nov 2015.

29. Arias P, Armesto J, Di-Capua D, González-Drigo R, Lorenzo H, Pérez-Gracia V. Digital photogrammetry, GPR and computational analysis of structural damages in a mediaeval bridge. Eng Fail Anal. 2007;14(8):1444-57. Accessed 3 Nov 2015.

30. Brumana R, Oreni D, Cuca B, Binda L, Condoleo P, Triggiani M. Strategy for integrated surveying techniques finalized to interpretive models in a Byzantine Church, Mesopotam, Albania. Int J Archit Herit. 2014;8(6):886-924. https://doi.org/10.1080/15583058.2012.756077.

31. Del Giudice M, Osello A. BIM for cultural heritage. Int Arch Photogramm Remote Sens Spat Inf Sci ISPRS Arch. 2013;40(5W2):225-9. http:// www.scopus.com/inward/record.url?eid=2-s2.0-84924330169\&partn erlD=tZOtx3y1. Accessed 1 Nov 2015.

32. Odgers D, Henry A. Practical building conservation: stone. Farnham: Ashgate, English He; 2012. p. 338.
33. McCaig I. Practical building conservation. Conservation basics. Farnham: English He, Ashgate; 2013. p. 384.

34. Williams J. NHSS report 2-the use of science to enhance our understanding of the past. 2009. www.heritagesciencestrategy.org.uk. Accessed 23 Feb 2016.

35. Historic England. Conservation principles, policies and guidance. 2008. https://content.historicengland.org.uk/images-books/publications/conse rvation-principles-sustainable-management-historic-environment/conse rvationprinciplespoliciesquidanceapr08web.pdf/. Accessed 17 Mar 2017

36. Williams J. NHSS Report 3-understanding capacity in the heritage science sector. 2009. www.heritagesciencestrategy.org.uk. Accessed 23 Feb 2016.

37. ICOMOS, ISCS. Illustrated glossary on stone deterioration patterns. 2008. http://www.icomos.org/publications/monuments_and_sites/15/pdf/ Monuments_and_Sites_15_ISCS_Glossary_Stone.pdf. Accessed 15 Aug 2016.

38. D'Agostino D, Congedo PM, Cataldo R. Computational fluid dynamics (CFD) modeling of microclimate for salts crystallization control and artworks conservation. J Cultur Herit. 2014;15(4):448-57.

39. Grau-Bové J, Mazzei L, Malki-Ephstein L, Thickett D, Strlič M. Simulation of particulate matter ingress, dispersion and deposition in a historical building. J Cultur Herit. 2016;18:199-208.

40. Lopez-Gonzalez L, de Cosca RO, Gomez-Heras M, Garcia-Morales S. A 4D GIS methodology to study variations in evaporation points on a heritage building. Environ Earth Sci. 2016;75(14):1113.

41. Koehl M, Viale A, Reeb S. A historical timber frame model for diagnosis and documentation before building restoration. ISPRS Ann Photogramm Remote Sens Spat Inf Sci. 2013;2(2)/W1:201-12. http://www.isprs -ann-photogramm-remote-sens-spatial-inf-sci.net/II-2-W1/201/2013/. Accessed 11 Nov 2015.

42. Tang $\mathrm{P}$, Huber D, Akinci B, Lipman R, Lytle A. Automatic reconstruction of as-built building information models from laser-scanned point clouds: a review of related techniques. Autom Constr. 2010;19(7):829-43. https:// doi.org/10.1016/j.autcon.2010.06.007.

43. Di Giulio R, Balzani M, Ferrari F. Digital morphometric survey for documentation, conservation and restoration works: the MUDI project. In: loannides M, Magnenat-Thalmann N, Fink E, Žarnić R, Yen A-Y, Quak E, editors. Digital heritage. Progress in cultural heritage: documentation, preservation, and protection: 5th international conference, EuroMed 2014, Limassol, Cyprus, November 3-8, 2014. Proceedings. Cham: Springer International Publishing; 2014. p. 617-24 (Lecture Notes in Computer Science; vol. 8740). http://link.springer.com/10.1007/978-3-319-13695-0.

44. Carpiceci M. II rilievo dello spazio architettonico Principi geometrici e grafici. Edizioni d. Roma: Kappa; 2000. p. 64.

45. Baila A, Mazza L, Anzani A. Design for knowledge and restoration. instrumental survey at Santa Maria in Celso. In: Ioannides M, MagnenatThalmann N, Fink E, Žarnić R, Yen A-Y, Quak E, editors. Cultural heritage: documentation, preservation, and protection: 5th international conference, EuroMed 2014, Limassol, Cyprus, November 3-8, 2014. Cham: Springer International Publishing; 2014. p. 427-37. (Lecture Notes in Computer Science; vol. 8740). http://link.springer.com/10.1007/978-3319-13695-0.

46. Balletti C, Brussa N, Gottardi C, Guerra F. The documentation and reintegration of a lost past. ISPRS Ann Photogramm Remote Sens Spat Inf Sci. 2014;2(5):49-55. http://www.isprs-ann-photogramm-remote-sens-spati al-inf-sci.net/II-5/49/2014/. Accessed 2 Nov 2015.

47. Cuca B, Agapiou A, Kkolos A, Hadjimitsis D. Integration of innovative surveying technologies for purposes of $3 \mathrm{D}$ documentation and valorisation of St. Herakleidios monastery. In: loannides M, Magnenat-Thalmann N, Fink E, Žarnić R, Yen A-Y, Quak E, editors. Cultural heritage: documentation, preservation, and protection: 5th international conference, EuroMed 2014, Limassol, Cyprus, November 3-8, 2014. Cham: Springer International Publishing; 2014. p. 387-95. (Lecture Notes in Computer Science; vol. 8740). http://link.springer.com/10.1007/978-3-319-13695-0.

48. Garagnani S. Building Information Modeling semantico e rilievi ad alta risoluzione di siti appartenenti al Patrimonio Culturale. DISEGNARECON. 2012;5(10):297-302. https://disegnarecon.unibo.it/article/view/3359. Accessed 10 Nov 2015.

49. Garagnani S. Building information modeling and real world knowledge: a methodological approach to accurate semantic documentation for the built environment. In: 2013 Digital heritage international congress 
(DigitalHeritage). IEEE; 2013. p. 489-96. http://ieeexplore.ieee.org/lpdocs/ epic03/wrapper.htm?arnumber=6743788. Accessed 10 Nov 2015.

50. Micoli L, Guidi G, Angheleddu D, Russo M. A multidisciplinary approach to 3D survey and reconstruction of historical buildings. In: 2013 digital heritage international congress (DigitalHeritage). IEEE; 2013. p. 241-8. http://ieeexplore.ieee.org/document/6744760/. Accessed 11 Nov 2015.

51. Suwardhi D, Menna F, Remondino F, Hanke K, Akmalia R. Digital 3D Borobudur-integration of 3D surveying and modeling techniques. ISPRS Int Arch Photogramm Remote Sens Spat Inf Sci. 2015;40(5)/W7:417-23. http://www.int-arch-photogramm-remote-sens-spatial-inf-sci.net/XL5-W7/417/2015/. Accessed 15 Nov 2015

52. Dore C, Murphy M. Semi-automatic generation of as-built BIM façade geometry from laser and image data. J Inf Technol Constr. 2014;19:20-46.

53. Beraldin J-A. Integration of laser scanning and close-range photogrammetry - the last decade and beyond. Int Arch Photogramm Remote Sens. 2004;35(Part B5):1031-42.

54. Rossi D. An image-based modelling experience about social facilities, built during the fascist period in middle-Italy. ISPRS Int Arch Photogramm Remote Sens Spat Inf Sci. 2012;38(5):83-9. http://www.int-arch-photo gramm-remote-sens-spatial-inf-sci.net/XXXVIII-5-W16/83/2011/isprsarchi ves-XXXVIII-5-W16-83-2011.pdf. Accessed 14 Nov 2015.

55. Manferdini AM, Galassi M. Assessments for 3 D reconstructions of cultural heritage using digital technologies. ISPRS Int Arch Photogramm Remote Sens Spat Inf Sci. 2013;40(5)/W1:167-74. http://www.int-arch-photo gramm-remote-sens-spatial-inf-sci.net/XL-5-W1/167/2013/isprsarchivesXL-5-W1-167-2013.pdf. Accessed 11 Nov 2015.

56. Kurdy M, Biscop J-L, De Luca L, Florenzano M. 3D Virtual anastylosis and the reconstruction of several buildings in the site of Saint-Simeon, Syria. ISPRS Int Arch Photogramm Remote Sens Spat Inf Sci. 2012;38(5):45-52. http://www.int-arch-photogramm-remote-sens-spatial-inf-sci.net/XXXV| II-5-W16/45/2011/. Accessed 11 Nov 2015.

57. Allen PK, Troccoli A, Smith B, Murray S, Stamos I, Leordeanu M. New methods for digital modeling of historic sites. Comput Graph Appl IEEE. 2003;23(6):32-41. http://ieeexplore.ieee.org/xpls/abs_all.jsp?arnum ber $=1242380$. Accessed 3 Nov 2015.

58. Basir WNFWA, Setan H, Majid Z, Chong A. Geospatial database for heritage building conservation. IOP Conf Ser Earth Environ Sci. 2014;18(1):12087. http://www.scopus.com/inward/record.url?eid=2s2.0-84902312411\&partnerlD=tZOtx3y1. Accessed 2 Nov 2015.

59. Oreni D, Brumana R, Della Torre S, Banfi F, Barazzetti L, Previtali M. Survey turned into HBIM: the restoration and the work involved concerning the Basilica di Collemaggio after the earthquake (L'Aquila). ISPRS Ann Photogramm Remote Sens Spat Inf Sci. 2014;2(5):267-73.

60. Oreni D, Brumana R, Banfi F, Bertola L, Barazzetti L, Cuca B, et al. Beyond crude 3D models: from point clouds to historical building information modeling via NURBS. In: loannides M, Magnenat-Thalmann N, Fink E, Žarnić R, Yen A-Y, Quak E, editors. Cultural heritage: documentation, preservation, and protection: 5th international conference, EuroMed 2014, Limassol, Cyprus, November 3-8, 2014. Cham: Springer International Publishing; 2014. p. 166-75 (Lecture Notes in Computer Science; vol. 8740). http://link.springer.com/10.1007/978-3-319-13695-0.

61. Quattrini R, Malinverni ES, Clini P, Nespeca R, Orlietti E. From TLS to HBIM. High quality semantically-aware $3 \mathrm{~d}$ modelling of complex architecture. ISPRS Int Arch Photogramm Remote Sens Spat Inf Sci. 2015;40(5)/ W4(5W4):367-74. http://www.int-arch-photogramm-remote-sens-spati al-inf-sci.net/XL-5-W4/367/2015/. Accessed 14 Nov 2015.

62. Barazzetti L, Banfi F, Brumana R, Gusmeroli G, Previtali M, Schiantarelli G. Cloud-to-BIM-to-FEM: structural simulation with accurate historic BIM from laser scans. Simul Model Pract Theory. 2015;57:71-87. https://doi. org/10.1016/j.simpat.2015.06.004.

63. British Standards Institution. PAS 1192-2:2013. Specification for information management for the capital/delivery phase of construction projects using Building Information Modelling. 2013.

64. BIM Industry Working Group. A report for the Government Construction Client Group—March 2011. Communications. 2011. http://www.bimta skgroup.org/wp-content/uploads/2012/03/BIS-BIM-strategy-Report.pdf. Accessed 25 Oct 2017.
65. Losciale LV, Lombardo J, De Luca L. New semantic media and 3D architectural models representation. In: 2012 18th international conference on virtual systems and multimedia. IEEE; 2012. p. 533-6. http://ieeexplore .ieee.org/document/6365970/. Accessed 11 Nov 2015.

66. Dore C, Murphy M. Semi-automatic techniques for as-built BIM façade modeling of historic buildings. In: 2013 digital heritage international congress (DigitalHeritage). IEEE; 2013. p. 473-80. http://ieeexplore.ieee. org/document/6743786/. Accessed 05 Nov 2015.

67. Remondino F, El-Hakim S. Image-based 3D modelling: a review. Photogramm Rec. 2006;21(115):269-91. https://doi.org/10.111 1/j.1477-9730.2006.00383.x.

68. Baik A. From point cloud to Jeddah heritage BIM Nasif historical housecase study. Digit Appl Archaeol Cultur Herit. 2017:4:1-18. https://doi. org/10.1016/j.daach.2017.02.001.

69. Stiny G, Gips J. Shape grammars and the generative specification of painting and sculpture. In: Inf Process 71 Proc IFIP Congr 1971. vol. 2, 1972.

70. Department for Culture Media and Sport. Scheduled monuments \& nationally important but non-scheduled monuments. 2013. http:// www.historic-scotland.gov.uk/index/heritage/searchmonuments.htm. Accessed 25 Oct 2017.

71. Gaiani M. Creare Sistemi informativi per studiare, conservare, gestire e comunicare sistemi architettonici e archeologici complessi. DisegnareCon. 2012;5(10):9-20.

72. English Heritage. Discovering the past, shaping the future: research strategy 2005-2010. 2005. http://www.english-heritage.org.uk/research. Accessed 23 Feb 2016.

73. Pauwels P, Bod R, Di Mascio D, De Meyer R. Integrating Building Information Modelling and semantic web technologies for the management of built heritage information. In: 2013 digital heritage international congress (DigitalHeritage). IEEE; 2013. p. 481-8. http://ieeexplore.ieee.org/docum ent/6743787/. Accessed 14 Nov 2015.

74. Stefani C, Busayarat C, Renaudin N, De Luca L, Véron P, Florenzano M. An image-based approach for the architectural modeling of past states. Int Arch Photogramm Remote Sens Spat Inf Sci. 2011;38:2-4. http://sam. ensam.eu/handle/10985/9806. Accessed 15 Nov 2015.

75. Percy K, Ward S, Quintero MS, Morrison T. Integrated digital technologies for the architectural rehabilitation \& conservation of Beinn Bhreagh Hall \& surrounding site, Nova Scotia, Canada. ISPRS Ann Photogramm Remote Sens Spat Inf Sci. 2015;2(5)/W3:235-41. http://search.proquest.com/ openview/68bddd48cbbd9eeaa5d7271a35528f80/1?pq-origsite=gscho $\mid$ ar\&cbl=2037681. Accessed 14 Nov 2015.

76. Sandrolini F, Franzoni E. An operative protocol for reliable measurements of moisture in porous materials of ancient buildings. Build Environ. 2006;41(10):1372-80.

77. Williams J. NHSS Report 1 -the role of science in the management of the UK's heritage. 2009

78. Science and Heritage. Details of the call for collaborative research studentships in science and heritage October 2007. 2007.

79. Bruno Jr A, Spallone R. Cultural heritage conservation and communication by digital modeling tools. Case studies: minor architectures of the thirties in the Turin area. ISPRS Ann Photogramm Remote Sens Spat Inf Sci. 2015;2(5)/W3:25-32. http://www.isprs-ann-photogramm-remot e-sens-spatial-inf-sci.net/II-5-W3/25/2015/. Accessed 2 Nov 2015.

80. English Heritage. Research Agenda : an introduction to English Heritage's research themes and programmes. London: English Heritage; 2005.

81. Fai S, Graham K, Duckworth T, Wood N, Attar R. Building Information Modelling and heritage documentation. In: Proceedings of the 23rd international symposium, international scientific committee for documentation of cultural heritage (CIPA). 2011. p. 12-6. https://www.semanticscholar .org/paper/Building-Information-Modelling-and-Heritage-Fai-Graham/ b76a6be1ab4c5c148757eac8c73dc7a5c2995999/pdf. Accessed 10 Nov 2015.

82. NHSS Steering Group. Our vision and strategy for heritage science. NHSS Vision \& Strategy. 2010. 